\title{
SISTEM INFORMASI GEOGRAFIS PENGGUNAAN LAHAN DAN PRODUKSI TANAMAN PANGAN KABUPATEN KEDIRI JAWA TIMUR
}

\author{
Antonius Septya Priya Pradana \\ Program Studi Teknik Informatika S1, Fakultas Teknologi Industri \\ Institut Teknologi Nasional Malang, Jalan Raya Karanglo km 2 Malang, Indonesia \\ antoniusseptya@gmail.com
}

\begin{abstract}
ABSTRAK
Informasi data komoditas sekarang ini masih disajikan dalam bentuk laporan statistik setiap tahunnya di setiap-setiap daerah. Dalam hal ini termasuk juga pada wilayah Kabupaten Kediri. Untuk saat ini Dinas Pertanian dan Perkebunan Kabupaten Kediri masih mengalami kesulitan memantau pertanian di Kabupaten Kediri karena luasnya wilayah dan belum ada sistem yang dapat membantu pendataan lahan pertanian dan hasil produksi tanaman pangan.

Sistem yang akan dibangun yaitu sebuah sistem informasi geografis penggunaan lahan dan produksi tanaman pangan. Dalam hal ini dengan adanya teknologi informasi ini langkah kedepannya akan lebih mempermudah untuk melihat lahan jenis tanaman pangan yang sudah ada maupun yang belum ada di suatu kecamatan tersebut.

Penerapan sistem informasi geografis ini bermanfaat untuk memberikan informasi letak wilayahwilayah kecamatan dari Kabupaten Kediri serta mengetahui beberapa lahan jenis tanaman yang terdapat di Kecamatan tersebut, dan memberikan informasi produksi hasil panennya dari tiap-tiap kecamatan.
\end{abstract}

Kata Kunci : Kabupaten Kediri, Jawa Timur, Tanaman Pangan, Sistem Informasi Geografis.

\section{PENDAHULUAN}

\subsection{Latar Belakang}

Wilayah Kabupaten Kediri secara geografis terletak pada koordinat antara $7^{\circ} 36^{\prime} 12^{\prime \prime}$, -

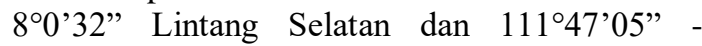
$112^{\circ} 18^{\prime 2} 20^{\prime \prime}$ Bujur Timur. Kabupaten Kediri memiliki luas wilayah sebesar $1.386,05 \mathrm{Km}^{2}$ atau $138.605 \mathrm{Ha}$ yang terbagi menjadi 26 kecamatan antara lain yaitu Kecamatan Mojo, Semen, Ngadiluwih, Kras, Ringinrejo, Kandat, Wates, Ngancar, Plosoklaten, Gurah, Puncu, Kepung, Kandangan, Pare, Badas, Kunjang, Plemahan, Purwoasri, Papar, Pagu, Kayenkidul, Gampengrejo, Ngasem, Banyakan, Grogol, dan Tarokan. Dari seluruh Kecamatan dalam Kabupaten Kediri terdapat lahan pertanian tanaman pangan yang dikelola oleh Dinas Pertanian dan Perkebunan Kabupaten Kediri. Jenis tanaman pangan yang diproduksi antara lain yaitu padi, jagung, ubi kayu, ubi jalar, kacang tanah, kedelai, dan kacang hijau. Sebagai sarana untuk memudahkan dalam mendapatkan informasi maka akan dibuatnya sebuah sistem geografis.

Memetakan dan menganalisis dari berbagai ragam hasil pertanian di beberapa kecamatan sangat membantu dinas pertanian dalam pengolahan lahan dan produksi tanaman pangan. Untuk saat ini Dinas Pertanian dan Perkebunan Kabupaten Kediri masih mengalami kesulitan memantau pertanian di Kabupaten Kediri karena luasnya wilayah dan belum ada sistem yang dapat membantu pendataan lahan pertanian dan hasil produksi tanaman pangan. Saat ini Dinas Pertanian dan Perkebunan Kabupaten Kediri masih menggunakan sistem yang manual. Penelitian ini dilakukan untuk mencari solusi dalam mengembangkan teknologi informasi. Dengan adanya teknologi informasi ini langkah kedepannya akan lebih mempermudah untuk melihat lahan jenis tanaman pangan yang sudah ada maupun yang belum ada di suatu kecamatan tersebut. Dari hasil penelitian ini diharapkan mampu membuat sistem informasi geografis yang bermanfaat sebagai sumber referensi pertanian dalam pengolahan lahan.

Penerapan sistem informasi geografis ini bermanfaat untuk mengetahui letak wilayahwilayah kecamatan dari Kabupaten Kediri serta mengetahui beberapa lahan jenis tanaman yang terdapat di kecamatan tersebut. Dari permasalahan diatas maka akan dibangun sebuah sistem informasi geografis, dengan adanya sistem informasi geografis ini diharapkan lebih mudah dan membantu pertanian dalam melakukan pemantauan luas panen dan hasil produksinya dari berbagai jenis tanaman pangan maupun dari berbagai kecamatan dalam Kabupaten Kediri. Adapun juga untuk mempermudah masyarakat yang ingin mengetahui informasi mengenai luas panen maupun hasil produksi tanaman pangan dari berbagai kecamatan. Oleh karena itu Sistem 
Informasi Geografis merupakan sistem yang dirancang untuk bekerja dengan data yang tereferensi secara spasial atau koordinatkoordinat geografis dan disusun berdasarkan analisis kebutuhan dan perancangan yang terstruktur sehingga tercapai tujuan dari pembuatan.

\subsection{Rumusan Masalah}

Berdasarkan latar belakang diatas, penulis dapat membuat suatu rumusan masalah yaitu :

1. Bagaimana merancang dan membangun sistem informasi geografis pemetaan lahan dan produksi tanaman pangan di Kabupaten Kediri Jawa Timur?

2. Bagaimana menginformasikan hasil produksi komoditas tanaman pangan yang terdapat di Kabupaten Kediri Jawa Timur dalam sebuah website?

\subsection{Tujuan}

Adapun tujuan yang ingin dicapai dalam penelitian ini adalah :

1. Merancang dan membangun sistem informasi geografis pemetaan lahan dan produksi tanaman pangan untuk mempermudah masyarakat mendapatkan informasi.

2. Menginformasikan data hasil produksi komoditas tanaman pangan yang terdapat di Kabupaten Kediri dari beberapa Kecamatan dalam sebuah website.

\subsection{Batasan Masalah}

Agar pembahasan ini tidak meluas, maka ditentukan beberapa batasan masalah diantaranya, adalah :

1. Data yang digunakan dalam penelitian ini adalah data dari Dinas Pertanian dan Perkebunan Kabupaten Kediri tahun 2017.

2. Data komoditas tanaman pangan yang digunakan pada sistem informasi geografis ini yaitu padi, jagung, ubi kayu, ubi jalar, kacang tanah, kacang hijau, dan kedelai.

3. Pembuatan peta digital dibuat menggunakan software ArcGIS.

4. Bahasa pemrograman yang digunakan adalah HTML, PHP, CSS Bootstrap.

\section{TINJAUAN PUSTAKA}

\subsection{Penelitian Terkait}

Pertanian menjadi salah satu sektor dari pendapatan masyarakat, banyak warga Indonesia yang bekerja sebagai petani. Sektor pertanian juga sangat membantu perkonomian masyarakat. Masyarakat Kabupaten Gorontalo bermayoritas mata pencaharian sebagai petani. Oleh karena itu Kabupaten Gorontalo akan membuat sistem informasi geografis berbasis website untuk pemetaan dan menganalisis hasil pertanian yang unggul di beberapa Kecamatan. Dari hasil penelitian menunjukkan bahwa Sistem Informasi Geografis mampu melakukan pemetaan untuk mengetahui dan menganalisis hasil pertanian yang unggul [1].

Salah satu komponen pangan adalah karbohidrat yang merupakan sumber energi bagi tubuh. Tanaman pangan di indonesia seperti padi, jagung, ubi kayu, dan ubi jalar merupakan sumber karbohidrat untuk manusia. Selain tanaman pangan yang mengandung karbohidrat, ada juga tanaman pangan yang mengandung protein. Tanaman pangan yang mengandung protein antara lain kacang tanah, kedelai, dan kacang hijau. Penelitian dilakukan untuk mengetahui potensi tanaman pangan yang ada pada Kabupaten Halmahera Barat. Oleh karena itu dibuatlah sistem informasi geografis untuk membantu mengetahui tanaman pangan yang ada di Kabupaten Halmahera Barat tanpa turun ke lokasi tersebut [2].

Tantangan dalam pengelolaan pertanian di Indonesia menuntut pengelolaan khusus untuk penguasaan di bidang teknologi dalam pemetaan luas lahan sawah. Bahkan belum semua petani yang dapat melakukan pengelolaan pertanian di bidang teknologi. Untuk mengatasi tantangan dan ancaman pertanian padi, maka solusi yang tepat yaitu membuat sebuah sistem informasi geografis. Dengan adanya sistem informasi geografis berbasis web dapat memberikan informasi pemetaan terkait luas lahan dan potensi tanaman padi. Dari hasil penelitian menunjukkan sistem informasi geografis dapat memberikan informasi bentuk pop-up pada peta dan pemantauan lahan tanaman padi [3].

\subsection{Tanaman Pangan}

Pangan merupakan kebutuhan pokok bagi seluruh penduduk di dunia untuk dikonsumsi dan menjadi sumber energi. Ketersediaan pangan yang ada harus mampu memenuhi kebutuhan pangan setiap penduduk. Di Indonesia, sebagian besar makanan pokok penduduknya adalah beras. Indonesia merupakan negara yang di anugerahi kesuburan tanah, yang dapat ditanami berbagai macam tanaman pangan lain seperti jagung salah satunya. Jagung dapat menjadi bahan makanan pokok altenatif kedua setelah padi (beras). Oleh karena itu ketersediaan jagung dalam hal ini adalah produksi jagung perlu mendapat pengawasan dan kajian lebih mendalam agar ketersediaannya juga memenuhi. Pembahasan ini akan membahas jenis tanaman pangan yang terdapat di Kabupaten Kediri. Jenis tanaman pangan yang ada di Kabupaten Kediri antara lain yaitu padi, jagung, ubi kayu, ubi jalar, kacang tanah, kedelai dan kacang hijau [4]. 


\subsection{Sistem Informasi Geografis}

Sistem Informasi Geografis (SIG) menjadi salah satu media penyimpanan informasi, terutama informasi yang berkaitan dengan data spasial. Sistem Informasi Geografis merupakan sebuah sistem informasi sumber daya lahan yang berkaitan dengan proses penyimpanan, pengolahan, penyajian data yang mempunyai banyak manfaat seperti untuk aplikasi dalam bidang pertanian, kehutanan, dan lain sebagainya. Sistem informasi geografis yaitu suatu sistem komputer yang mempunyai kemampuan untuk membangun, mengelola, menganalisa, menyimpan dan menampilkan suatu informasi geografis dalam bentuk pemetaan dimana user yang membangun data serta mengoperasikannya juga termasuk dari bagian sistem tersebut [5].

\section{METODE PENELITIAN}

\subsection{Analisis Sistem}

Sistem Informasi Geografis menjadi salah satu media penyimpanan informasi yang berkaitan dengan data spasial, sistem informasi geografis merupakan suatu sistem komputer yang mempunyai kemampuan untuk membangun, mengelola, menganalisa, menyimpan dan menampilkan suatu informasi geografis dalam bentuk pemetaan. Lahan pertanian tanaman pangan yang ada di Kabupaten Kediri sangat luas, untuk mempermudah mengetahui informasi produksi tanaman pangan dari berbagai kecamatan diperlukan suatu sistem yang dapat memberikan informasi produksi tanaman pangan yang ada di Kabupaten Kediri. Oleh karena itu untuk memberikan suatu informasi produksi tanaman pangan, penulis akan membuat sistem informasi geografis.

\subsection{Sistem Yang Akan Dibangun}

Sistem yang akan dibangun yaitu sistem informasi geografis penggunaan lahan dan produksi tanaman pangan Kabupaten Kediri yang bertujuan untuk mempermudah masyarakat atau orang awan melihat peta Kabupaten Kediri serta mengetahui Kecamatan-Kecamatan dalam Kabupaten Kediri dan mengetahui informasi produksi tanaman pangan dari berbagai Kecamatan dalam Kabupaten Kediri.

\subsection{Desain Arsitektur Sistem}

Dalam sistem informasi geografis penggunaan lahan dan produksi tanaman pangan Kabupaten Kediri Jawa Timur dilakukan pemetaan wilayah berdasarkan Kecamatan dari Kabupaten Kediri, terlihat seperti pada gambar 3.1

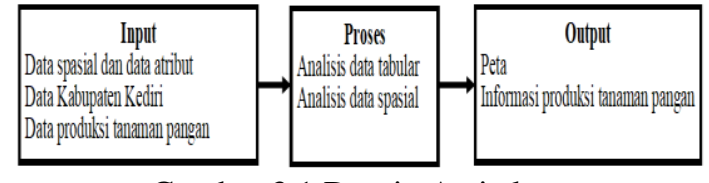

Gambar 3.1 Desain Arsitektur

Dari desain arsitektur pada gambar 3.1 diatas terdapat input, proses, dan output, berikut penjelasan mengenai desain tersebut :

1. Input

a. Data spasial dan data atribut

Data spasial adalah gambaran suatu wilayah yang terdapat di permukaan bumi. Sedangkan data atribut yaitu data berisi informasi yang dimiliki oleh obyek dalam data spasial.

b. Data Kabupaten Kediri

Data Kecamatan yang ada di dalam Kabupaten Kediri.

c. Data produksi tanaman pangan

Data produksi dan luas panen tanaman pangan dari berbagai Kecamatan.

2. Proses

a. Analisis data tabular

Menganalisa data dalam bentuk tabel.

b. Analisis data spasial

Menganalisis data untuk dibuat menjadi peta.

3. Output

a. Peta

Peta vektor

b. Informasi produksi tanaman pangan

Informasi mengenai hasil produksi dan luas panen tanaman pangan dari berbagai Kecamatan di Kabupaten Kediri.

\subsection{Flowchart User}

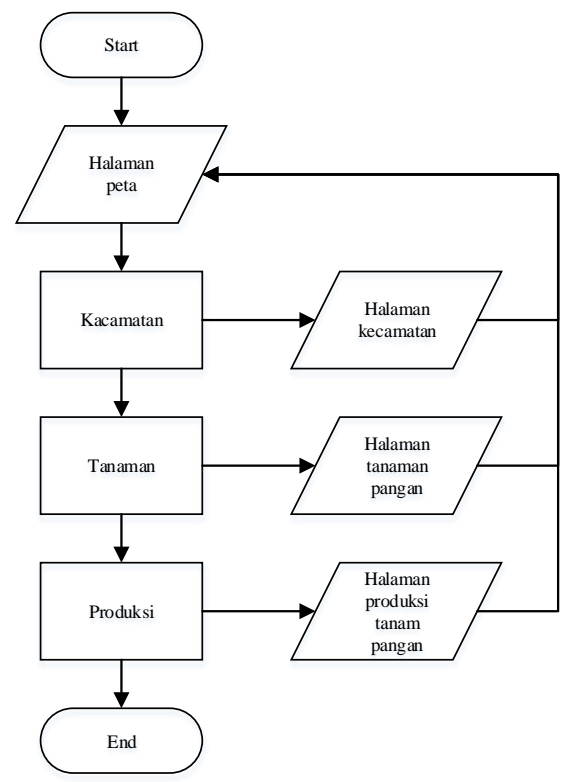

Gambar 3.2 Flowchart User 
Flowchart user pada gambar 3.2 dimulai dari halaman peta yang memuat tampilan peta Kabupaten Kediri. Selain itu user juga dapat mengakses menu halaman Kecamatan yang berisi data Kecamatan, menu halaman tanaman pangan berisi data tanaman pangan, dan menu halaman produksi berisi informasi produksi tanaman pangan.

\subsection{Desain Database}

\section{Tabel User}

Tabel user merupakan tabel yang digunakan untuk menyimpan data admin yang dapat login ke dalam website. Tabel user ditunjukkan pada tabel 3.1.

Tabel 3.1 Struktur Tabel User

\begin{tabular}{|l|l|l|l|l|}
\hline No & $\begin{array}{l}\text { Nama } \\
\text { Field }\end{array}$ & $\begin{array}{l}\text { Tipe } \\
\text { Data }\end{array}$ & Size & Keterangan \\
\hline 1 & iduser & Varchar & 10 & $\begin{array}{l}\text { Primary } \\
\text { Key }\end{array}$ \\
\hline 2 & username & Varchar & 50 & - \\
\hline 3 & pswd & Varchar & 50 & - \\
\hline
\end{tabular}

\section{Tabel Kecamatan}

Tabel Kecamatan merupakan tabel yang digunakan untuk menyimpan data Kecamatan di Kabupaten Kediri. Tabel Kecamatan ditunjukkan pada tabel 3.2.

Tabel 3.2 Struktur Tabel Kecamatan

\begin{tabular}{|l|l|l|l|l|}
\hline No & $\begin{array}{l}\text { Nama } \\
\text { Field }\end{array}$ & $\begin{array}{l}\text { Tipe } \\
\text { Data }\end{array}$ & Size & Keterangan \\
\hline 1 & idkec & Varchar & 10 & $\begin{array}{l}\text { Primary } \\
\text { Key }\end{array}$ \\
\hline 2 & nmkec & Varchar & 30 & - \\
\hline
\end{tabular}

\section{Tabel Jenis Tanaman}

Tabel jenis tanaman merupakan tabel yang digunakan untuk menyimpan data tanaman pangan di Kabupaten Kediri. Tabel jenis tanaman ditunjukkan pada tabel 3.3.

Tabel 3.3 Struktur Tabel Jenis Tanaman

\begin{tabular}{|l|l|l|l|l|}
\hline No & $\begin{array}{l}\text { Nama } \\
\text { Field }\end{array}$ & $\begin{array}{l}\text { Tipe } \\
\text { Data }\end{array}$ & Size & Keterangan \\
\hline 1 & idtanaman & Varchar & 10 & Primay Key \\
\hline 2 & nmtanaman & Varchar & 25 & - \\
\hline
\end{tabular}

\section{Tabel Produksi}

Tabel Produksi merupakan tabel yang digunakan untuk menyimpan data Produksi tanaman pangan dan luas laham panen di Kabupaten Kediri. Tabel produksi ditunjukkan pada tabel 3.4 .
Tabel 3.4 Struktur Tabel Produksi

\begin{tabular}{|l|l|l|l|l|}
\hline No & $\begin{array}{l}\text { Nama } \\
\text { Field }\end{array}$ & $\begin{array}{l}\text { Tipe } \\
\text { Data }\end{array}$ & Size & Keterangan \\
\hline 1 & idprod & Varchar & 20 & $\begin{array}{l}\text { Primary } \\
\text { Key }\end{array}$ \\
\hline 2 & nmkec & Varchar & 25 & - \\
\hline 3 & nmtanaman & Varchar & 20 & - \\
\hline 4 & tahun & Varchar & 5 & - \\
\hline 5 & luas_panen & Varchar & 50 & - \\
\hline 6 & produksi & Varchar & 50 & - \\
\hline 7 & rata & Varchar & 50 & - \\
\hline
\end{tabular}

\section{HASIL DAN PEMBAHASAN}

\subsection{Halaman Peta User}

Halaman peta atau sebagai halaman utama ketika user atau masyarakat mengakses website sistem informasi geografis Kabupaten Kediri tanpa harus melakukan proses login terlebih dahulu. Halaman peta pada sistem informasi geografis akan menampilkan peta Kabupaten Kediri, halaman peta user seperti pada gambar 4.1.

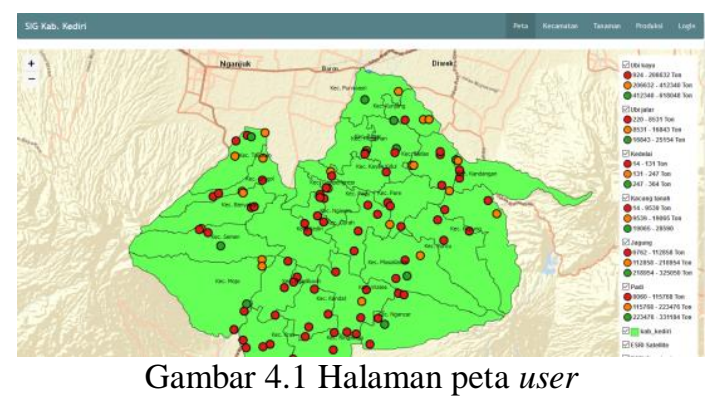

\subsection{Halaman Data Kecamatan}

Halaman data Kecamatan, pada halaman ini user dapat melihat Kecamatan-Kecamatan yang ada dalam Kabupaten Kediri, tampilan halaman data Kecamatan seperti pada gambar 4.2.

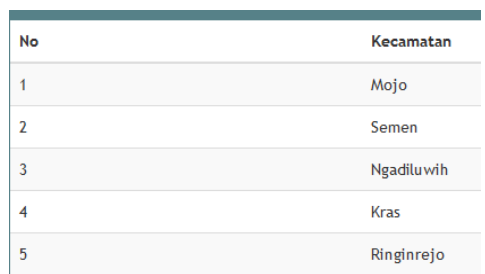

Gambar 4.2 Halaman data Kecamatan user

\subsection{Halaman Data Jenis Tanaman}

Halaman data jenis tanaman pangan, pada halaman ini user dapat melihat jenis tanaman yang sedang dikelola oleh Dinas Pertanian, tampilan halaman jenis tanaman pangan seperti pada gambar 4.3. 


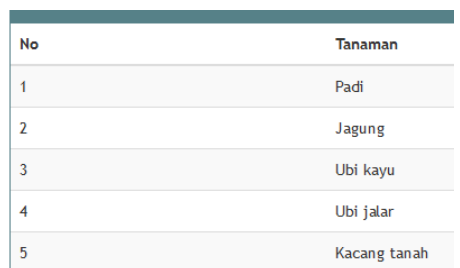

Gambar 4.3 Halaman jenis tanaman user

\subsection{Halaman Data Produksi}

Pada halaman data produksi user dapat melihat hasil produksi dan luas panen berbagai tanaman pangan dari berbagai Kecamatan dalam Kabupaten Kediri, tampilan halaman data produksi seperti pada gambar 4.4.

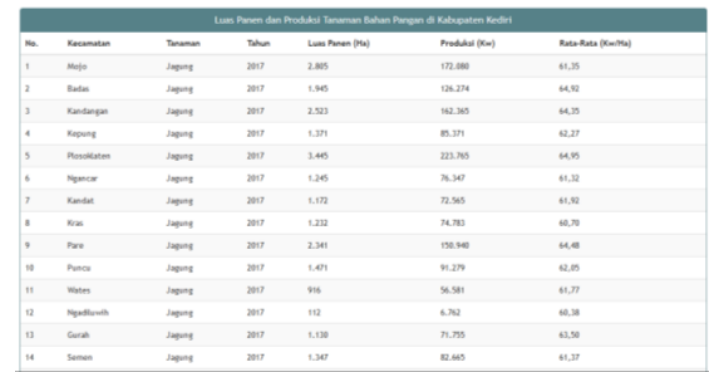

Gambar 4.4 Halaman data produksi user

\subsection{Halaman Login Admin}

Halaman login merupakan halaman yang pertama diakses oleh admin ketika akan melakukan pengolahan data seperti tambah, ubah, dan hapus data Kecamatan, jenis tanaman pangan, dan produksi tanaman pangan, tampilan halaman login seperti pada gambar 4.8.

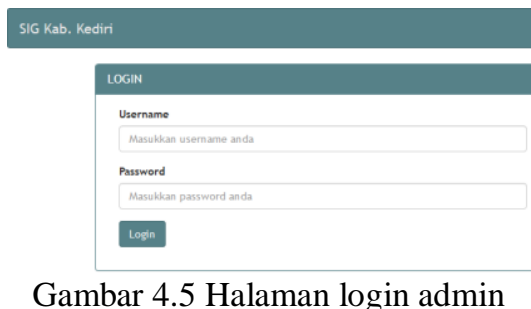

\subsection{Pengujian Fungsional Sistem}

Pengujian fungsional sistem merupakan proses menampilkan sistem dengan maksud untuk menemukan adanya kesalahan atau tidak pada sistem sebelum sistem dipublikasikan untuk digunakan oleh masyarakat atau pengguna. Hasil pengujian sistem ditunjukkan pada Tabel 4.1 sebagai berikut :
Tabel 4.1 Pengujian fungsional

\begin{tabular}{|c|c|c|}
\hline Akses & Pengujian & Hasil \\
\hline \multirow{6}{*}{ User } & $\begin{array}{l}\text { Halaman } \\
\text { tampilan peta }\end{array}$ & $\begin{array}{l}\text { Dapat } \\
\text { menampilkan } \\
\text { peta Kabupaten } \\
\text { Kediri }\end{array}$ \\
\hline & $\begin{array}{l}\text { Informasi data } \\
\text { pada setiap point }\end{array}$ & $\begin{array}{l}\text { Dapat } \\
\text { menampilkan } \\
\text { informasi data } \\
\text { pada setiap } \\
\text { point atau titik } \\
\text { yang dipilih }\end{array}$ \\
\hline & $\begin{array}{l}\text { Fitur zoom in dan } \\
\text { zoom out } \\
\text { tampilan peta }\end{array}$ & $\begin{array}{l}\text { Dapat } \\
\text { melakukan } \\
\text { zoom in maupun } \\
\text { zoom out }\end{array}$ \\
\hline & $\begin{array}{l}\text { Halaman data } \\
\text { Kecamatan }\end{array}$ & $\begin{array}{l}\text { Dapat } \\
\text { menampilkan } \\
\text { daftar data } \\
\text { Kecamatan } \\
\end{array}$ \\
\hline & $\begin{array}{l}\text { Halaman data } \\
\text { tanaman pangan }\end{array}$ & $\begin{array}{l}\text { Dapat } \\
\text { menampilkan } \\
\text { data tanaman } \\
\text { pangan }\end{array}$ \\
\hline & $\begin{array}{l}\text { Halaman } \\
\text { produksi } \\
\text { tanaman pangan }\end{array}$ & $\begin{array}{l}\text { Dapat } \\
\text { menampilkan } \\
\text { data produksi } \\
\text { tanaman }\end{array}$ \\
\hline \multirow{4}{*}{ Admin } & Login admin & $\begin{array}{l}\text { Dapat } \\
\text { melakukan login } \\
\text { dan masuk } \\
\text { sebagai admin }\end{array}$ \\
\hline & $\begin{array}{l}\text { Menambah data } \\
\text { kecamatan, } \\
\text { tanaman pangan, } \\
\text { dan produksi } \\
\text { tanaman pangan }\end{array}$ & $\begin{array}{l}\text { Dapat } \\
\text { melakukan } \\
\text { penambahan } \\
\text { data baru dan } \\
\text { menyimpan ke } \\
\text { database }\end{array}$ \\
\hline & $\begin{array}{l}\text { Merubah data } \\
\text { kecamatan, } \\
\text { tanaman pangan, } \\
\text { dan produksi } \\
\text { tanaman pangan } \\
\end{array}$ & $\begin{array}{l}\text { Dapat } \\
\text { melakukan } \\
\text { perubahan data } \\
\text { dan merubah } \\
\text { data di database }\end{array}$ \\
\hline & $\begin{array}{l}\text { Menghapus data } \\
\text { kecamatan, } \\
\text { tanaman pangan, } \\
\text { dan produksi } \\
\text { tanaman pangan }\end{array}$ & $\begin{array}{l}\text { Dapat } \\
\text { menghapus data } \\
\text { di database }\end{array}$ \\
\hline
\end{tabular}

\subsection{Pengujian Pada Web Browser}

Pengujian pada web browser merupakan proses untuk menemukan kekurangan dari sistem yang dibuat terhadap beberapa web browser seperti mozilla firefox, google chrome, opera mini, dan microsoft edge yang akan menjadi pengujian sebelum sistem dipublikasikan untuk digunakan oleh pengguna. Hasil pengujian sistem ditunjukkan pada Tabel 4.2 sebagai berikut : 
Tabel 4.2 Pengujian web browser

\begin{tabular}{|c|c|c|c|c|c|c|c|c|c|c|}
\hline \multirow[b]{3}{*}{ Akses } & \multicolumn{5}{|c|}{ Tabel 4.2 Pengujian web browser } & \multirow[b]{3}{*}{2} & \multirow[b]{3}{*}{$\begin{array}{l}\text { Halaman } \\
\text { data } \\
\text { Kecamatan }\end{array}$} & \multirow{3}{*}{$\begin{array}{l}\text { Menampilkan } \\
\text { data yang } \\
\text { telah } \\
\text { dimasukkan } \\
\text { atau data } \\
\text { yang ada di } \\
\text { database }\end{array}$} & \multirow[b]{3}{*}{$\begin{array}{l}\text { Menampilkan } \\
\text { data pada } \\
\text { halaman data } \\
\text { Kecamatan }\end{array}$} & \multirow[b]{3}{*}{ Sesuai } \\
\hline & \multirow[b]{2}{*}{ Pengujian } & \multicolumn{4}{|c|}{ Web Browser } & & & & & \\
\hline & & $\begin{array}{l}\text { Mozilla } \\
\text { Firefox } \\
\text { Versi } \\
\text { 68.0.1 }\end{array}$ & $\begin{array}{l}\text { Google } \\
\text { Chrome } \\
\text { Versi } \\
\text { 75.0. } \\
\text { 3770. } \\
\text { 142 }\end{array}$ & $\begin{array}{l}\text { Opera } \\
\text { Mini } \\
\text { Versi } \\
\text { 62.0. } \\
\text { 3331. } \\
\text { 72 }\end{array}$ & $\begin{array}{l}\text { Microsoft } \\
\text { Edge } \\
\text { Versi } \\
44.18362 . \\
1.0\end{array}$ & & & & & \\
\hline \multirow[b]{6}{*}{ Admin } & $\begin{array}{l}\text { Halaman } \\
\text { login. }\end{array}$ & $\sqrt{ }$ & $\sqrt{ }$ & $\sqrt{ }$ & $\sqrt{ }$ & \multirow{4}{*}{3} & \multirow{4}{*}{$\begin{array}{l}\text { Halaman } \\
\text { input data } \\
\text { Kecamatan }\end{array}$} & \multirow{4}{*}{$\begin{array}{l}\text { Memasukkan } \\
\text { data } \\
\text { Kecamatan } \\
\text { dan data } \\
\text { Kecamatan } \\
\text { tersebut } \\
\text { tersimpan di } \\
\text { database }\end{array}$} & \multirow{4}{*}{$\begin{array}{l}\text { Data berhasil } \\
\text { di simpan di } \\
\text { database }\end{array}$} & \multirow{4}{*}{ Sesuai } \\
\hline & $\begin{array}{l}\text { Halaman } \\
\text { peta admin. }\end{array}$ & $\sqrt{ }$ & $\sqrt{ }$ & $\sqrt{ }$ & $\sqrt{ }$ & & & & & \\
\hline & $\begin{array}{l}\text { Informasi } \\
\text { data pada } \\
\text { peta }\end{array}$ & $\sqrt{ }$ & $\sqrt{ }$ & $\sqrt{ }$ & $\sqrt{ }$ & & & & & \\
\hline & $\begin{array}{l}\text { Fitur zoom } \\
\text { pada peta }\end{array}$ & $\sqrt{ }$ & $\sqrt{ }$ & $\sqrt{ }$ & $\sqrt{ }$ & & & & & \\
\hline & $\begin{array}{l}\text { Hecamatan, } \\
\text { melakukan } \\
\text { tambah, } \\
\text { edit, dan } \\
\text { hapus data } \\
\text { Kecamatan. }\end{array}$ & $\sqrt{ }$ & $\sqrt{ }$ & $\sqrt{ }$ & $\sqrt{ }$ & 4 & $\begin{array}{l}\text { Halaman } \\
\text { edit data } \\
\text { Kecamatan }\end{array}$ & $\begin{array}{l}\text { Mengubah } \\
\text { data } \\
\text { Kecamatan } \\
\text { yang sudah } \\
\text { ada di dalam } \\
\text { database }\end{array}$ & $\begin{array}{l}\text { Pengubahan } \\
\text { data berhasil }\end{array}$ & Sesuai \\
\hline & $\begin{array}{l}\text { Kecamatan. } \\
\text { Halaman } \\
\text { tanaman, } \\
\text { melakukan } \\
\text { tambah, } \\
\text { edit, dan }\end{array}$ & $\sqrt{ }$ & $\sqrt{ }$ & $\sqrt{ }$ & $\sqrt{ }$ & 5 & $\begin{array}{l}\text { Halaman } \\
\text { hapus data } \\
\text { Kecamatan }\end{array}$ & $\begin{array}{l}\text { Menghapus } \\
\text { data } \\
\text { Kecamatan di } \\
\text { dalam } \\
\text { database }\end{array}$ & $\begin{array}{l}\text { Proses hapus } \\
\text { data berhasil }\end{array}$ & Sesuai \\
\hline
\end{tabular}

\subsection{Pengujian Kuesioner}

Pengujian kuesioner ini yaitu memberikan sebuah pertanyaan kepada pengguna atau user untuk memberikan penilaian pada sistem informasi geografis yang dibangun. Tabel hasil pengujian kuesioner ditunjukkan pada tabel 4.4.

Tabel 4.4 Pengujian kuesioner

\begin{tabular}{|c|c|c|c|c|c|}
\hline No & Pertanyaan & 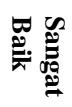 & 焉 & 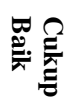 & 䙳. \\
\hline 1 & $\begin{array}{lr}\text { Bagaimana } & \text { menurut } \\
\text { saudara } & \text { dari } \\
\text { tampilan peta } & \text { pada } \\
\text { webgis ini? }\end{array}$ & 4 & 4 & 2 & 1 \\
\hline 2 & $\begin{array}{l}\text { Bagaimana menurut } \\
\text { saudara mengenai } \\
\text { informasi pop-up } \\
\text { pada peta dari tiap- } \\
\text { tiap point atau titik } \\
\text { ketika di klik? }\end{array}$ & 2 & 7 & 2 & 0 \\
\hline 3 & $\begin{array}{lr}\text { Bagaimana } & \text { menurut } \\
\text { saudara mengenai } \\
\text { tampilan desain } \\
\text { website ini? }\end{array}$ & 6 & 3 & 1 & 1 \\
\hline 4 & $\begin{array}{lr}\begin{array}{l}\text { Apakah } \\
\text { sistem }\end{array} & \text { website } \\
\text { geografis } & \text { mudah } \\
\text { digunakan? } & \\
\end{array}$ & 4 & 7 & 0 & 0 \\
\hline 5 & $\begin{array}{l}\text { Apakah website ini } \\
\text { membantu untuk } \\
\text { mendapatkan sebuah } \\
\text { informasi produksi } \\
\text { dan luas lahan } \\
\text { tanaman pangan? }\end{array}$ & 1 & 9 & 1 & 0 \\
\hline & Persentase hasil & 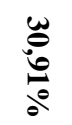 & 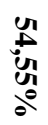 & 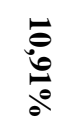 & 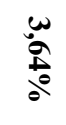 \\
\hline
\end{tabular}


Dari hasil pengujian terhadap kuesioner yang diberikan kepada pengguna seperti pada tabel 4.4, kesimpulan yang diperoleh dari pengguna menyatakan sistem informasi geografis $30,91 \%$ sangat baik, $54,55 \%$ baik, $10,91 \%$ cukup baik dan 3,64\% kurang baik.

\section{KESIMPULAN DAN SARAN \\ 5.1 Kesimpulan}

Dari perancangan dan implementasi website sistem informasi geografis penggunaan lahan dan produksi tanaman pangan di Kabupaten Kediri Jawa Timur, maka kesimpulan yang dapat diambil yaitu :

1. Sistem informasi geografis memberikan informasi peta digital lahan produksi tanaman pangan wilayah Kabupaten Kediri Jawa Timur dan informasi hasil produksi tanaman pangan pada tahun 2017 .

2. Berdasarkan dari hasil pengujian fungsional website sistem informasi geografis penggunaan lahan dan produksi tanaman pangan di Kabupaten Kediri Jawa Timur berjalan dengan baik, pengujian menggunakan web browser mozilla firefox versi 68.0.1, google chrome versi 75.0.3770.142, microsoft edge versi 44.18362.1.0, dan opera mini versi 62.0.3331.72. Serta dapat memberikan informasi mengenai hasil produksi tanaman pangan dari berbagai Kecamatan.

\subsection{Saran}

Agar dalam aplikasi ini berjalan dengan baik kedepannya, maka perlu dilakukannya perkembangan terhadap sistem informasi geografis dengan mengembangkan pada perangkat mobile.

\section{DAFTAR PUSTAKA}

[1] Ahaliki, B., 2016. SISTEM INFORMASI GEOGRAFIS (SIG) PEMETAAN DAN ANALISIS DAERAH PERTANIAN DI KABUPATEN GORONTALO. Jurnal Technopreneur (JTech), 4(2), pp.116-122.

[2] Ambarita, A., 2017 Sistem Informasi Geografis Potensi Tanaman Pangan (Studi Kasus: Kabupaten Halmahera Barat Provinsi Maluku Utara). IJNS-Indonesian Journal on Networking and Security, 6(1).

[3] Soelistio, A.T., Wibowo, T.A. and Permana, A.G., 2015. Aplikasi Sistem Informasi Geografis (Sig) Untuk Pengelolaan Padi Di Pulau Jawa Berbasis Web.eProceedings of Applied Science, 1(1).

[4] Erviyana, P., 2014. Faktor-Faktor yang Mempengaruhi Produksi Tanaman Pangan Jagung Di Indonesia. JEJAK: Jurnal Ekonomi dan Kebijakan, 7(2).

[5] Lestari, U., Triyono, J. and Ardianto, J., 2017. SISTEM PEMETAAN AREA PERSAWAHAN DESA GANTUNG KABUAT EN BELITUNG TIMUR BERBASIS GEORAPHICAL INFORMATION SYSTEM. PROSIDING SENSEI 2017, 1(1).

[6] Rohim, W.N., Awaluddin, M. and Suprayogi, A., 2015. Semarang Charity Map, Penyajian Peta Donasi Sosial Kota Semarang Berbasis Blogger Javascript. Jurnal Geodesi Undip,4(2), pp.117-130. 